\title{
PROFILES AND MOTIVATIONAL FACTORS OF INTERNATIONAL MIGRANT WORKERS IN THE LANGKAWI TOURISM AND HOSPITALITY INDUSTRY
}

\author{
Nurhazani MOHD SHARIFF* \\ School of Tourism, Hospitality \& Event Management, COLGIS, University \\ Utara Malaysia, 06010, Sintok, Kedah, Malaysia, e-mail: hazani@uum.edu.my
}

\section{Azlan ZAINOL ABIDIN}

School of Languages, Civilization \& Philosophy, CAS, University Utara Malaysia, 06010, Sintok, Kedah, Malaysia, e-mail: azlan@uum.edu.my

\begin{abstract}
Citation: MOHD SHARIFF, N., \& ZAINOL ABIDIN, A. (2019). PROFILES AND MOTIVATIONAL FACTORS OF INTERNATIONAL MIGRANT WORKERS IN THE LANGKAWI TOURISM AND HOSPITALITY INDUSTRY. GeoJournal of Tourism and Geosites, 24(1), 237-245. https://doi.org/10.30892/gtg.24118-355
\end{abstract}

\begin{abstract}
A study was undertaken to understand the profiles of international migrant workers and factors which motivate them to work in the Langkawi tourism and hospitality industry. The findings highlighted that most of the respondents were male and had been working in the industry for almost 5 years. Majority were single and came from Indonesia. They had been working in the accommodation sector and majority of them hold post in the customer service sector. Additionally, their received income of lower than $\mathrm{RM}_{5}, 000$. It was noted that most respondents had considered to work in Langkawi because they wanted to gain new experience. Surprisingly, high wages was considered by the respondents as the least motivational factor. The study concluded that it is essential to understand their profiles and factors motivating them as it could be used to plan for better policy and regulation regarding the recruitment of more migrant workers in the future.
\end{abstract}

Key words: International migrant worker, tourism and hospitality industry, profiles, motivational factors, Langkawi

\section{INTRODUCTION}

Nowadays, the tourism and hospitality industry is considered as one of the global economic sectors which significantly provide opportunities for employment (Baum, 2012). The tourism and hospitality employment is also believed to create several benefits such as information on regional synthesis, spatial analyses, and the human environment and can be extremely attractive to destination areas seeking economic development alternatives, when in a period of economic transition (Halseth, 1999).

\footnotetext{
* Corresponding author
} 
However, as the demand for workers in the industry is continuously growing quite rapidly in line with the growth of the industry itself, retaining the workers has becoming a barrier to the employers (Joppe, 2012). It is a fact that the tourism and hospitality industry plays essential role in increasing the growth of a country's economy. Hence, it is a challenge for the employers within the industry to employ international migrant workers (Janta et al., 2011). Previous studies also indicated that there is a relationships between tourism employment and migrant workers due to the labor shortages in the industry (Choi et al., 2000; William \& Hall, 2000).

According to Wickramasekara (2002), Asia presents many facets of labour migration within the hotel industry and beyond. In Malaysia for instance, the Workforce Department (2004) reported that by March 2004, there was 1.2 million international migrant workers with 77,149 were working in the service sectors including tourism and hospitality. Further, there were about 2.07 million migrant workers working in Malaysia in 2014 (Department of Labor Peninsular Malaysia, 2014). Based on the current data for 2015, the international migrant workers in Malaysia from various country has developed more than the previous years. Moreover, it also stated that over half of regular migrant workers during the last 15 years come from neighbouring country Indonesia (Figure 1).

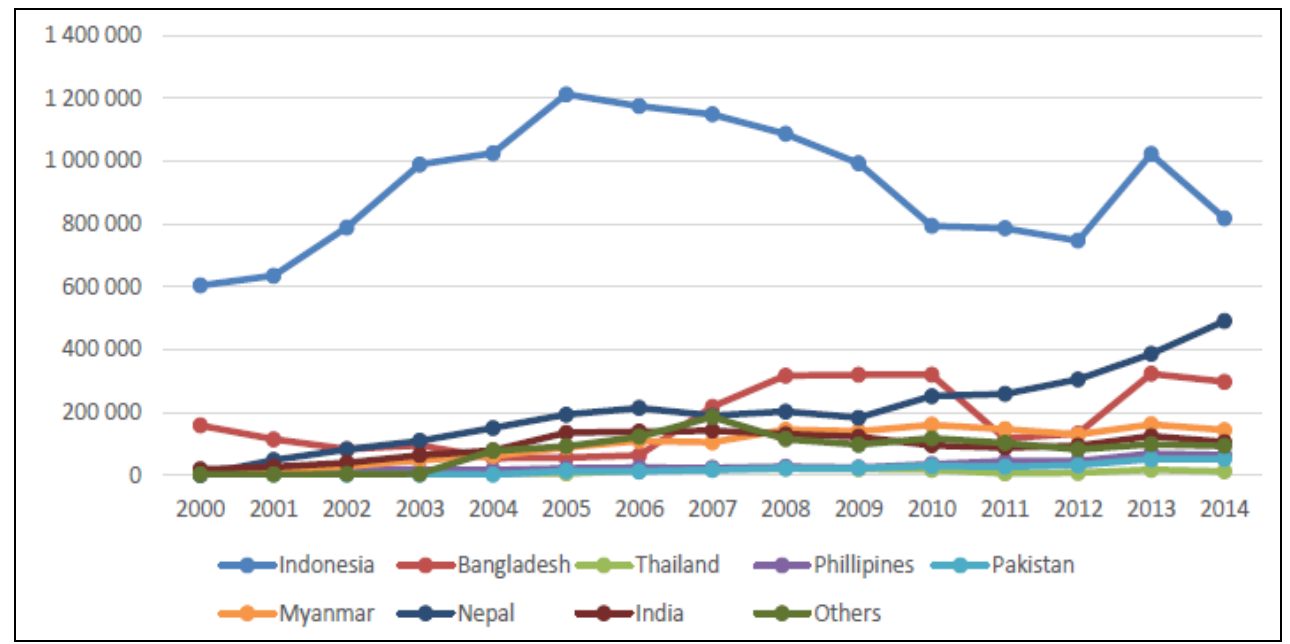

Figure 1. International migrant workers in Malaysia (Source: Ministry of Home Affair, 2015)

However, the tourism and hospitality industry is expected to have a difficult time attracting and keeping workers. According to Saunders (1981), the industry is considered unpopular as an employment choice due to its low status and large surplus of unskilled worker. In fact, as noted by the CTHRC (2003), there is also a concern that the industry will experience a shortage in the near future while the estimates of the number of jobs in tourism and hospitality continue to grow. Further studies also noted that the industry largely has an image of providing low skilled and low paying jobs, and attributes that are not likely to motivate mobility into the industry (Krakover, 2000; Hjalager \& Andersen, 2001).

\section{The case study - Langkawi, Malaysia}

The development of Langkawi as tourism destination has begun with the conferring on the Duty Free Zone status in 1987, hence have led to a more systematic development of the island which eventually transformed it into the modern tourist destination. The number 
of tourist arrivals in Langkawi has significantly increased for 2004 where it received 2.2 million tourist arrivals out of the $\mathbf{1 5 . 7}$ million received for Malaysia. Even though the number dropped slightly in 2005 to 1.8 million due to the post tsunami impact, Langkawi still remains as one of the top tourist destinations for Malaysia (Tourism Malaysia, 2016; LADA, 2016). The developments that are taking place in Langkawi have brought socioeconomic changes to the island's population. Further, the government, private sectors and local communities have also experienced a considerable amount of economic development as a result of the booming tourism industry in Langkawi (Anand \& Sen, 2000).

In 2012, Langkawi has received about $\mathrm{RM} 2.6$ billion revenue from the approximately 3 million recorded tourist arrivals. The government has taken prompt action from these statistics by proposing a Blueprint Langkawi by the year 2015 to make Langkawi Island listed as 10 highest island visited by tourists as well as to make Langkawi as a luxury tourist destination. Added to this, the target in economics is to double tourism in Langkawi Gross National Income (GNI) of RM 0.8 billion in 2010 to RM 1.9 billion in 2015 . Further, recipients are also expected to double from RM 1.9 billion tourists in 2010 to RM 3.8 billion in 2015 through the launching of marketing campaign based on customer needs. The major purpose of this marketing is to enhance the itinerary of foreign countries to Langkawi and product marketing in the luxury market and high spending tourists. At the same time, to create more job opportunities particularly in hotels and retails stores, more accommodations and commercial zones are expected to be developed.

\section{Problem Statement and Objective}

It is noticed that the issues of tourism worker shortages in some developed countries are due to the fact of low wages and social stigma (International Labour Office, 1989) thus it is difficult to design a suitable methodology to measure and analyse the data related to skills shortages. In addition, Cukier-Snow and Wall (1993) also emphasized that the tourism and hospitality as an industry with low-paying, low skill and even low value-added when it comes to worker management aspect. Similarly, Pantelidis and Wrobel (2008) in their study found that migrant employees is becoming increasingly important for the economic sustainability of the hospitality sector as the workers are considered as a cheap and accessible source of low-skilled labour.

To fulfill the vacancy of workers, Malaysia has practiced and accepted the foreign workers policy beginning 1990 for the recruitment of semi and unskills workers in the industry. This scenario has significantly shown the needs of foreign workers to fulfill the workforce demand specifically in the tourism and hospitality industry (Ajis et al., 2014). In spite of the large number of international migrant workers and the problems associated with their presence, the Malaysian government is yet to come up with a comprehensive policy on the issue. Furthermore, previous studies did not focus on developing the international migrant workers pattern. Therefore, it is important to study and understand their profiles and factors motivating them to work in the industry.

\section{LITERATURE REVIEW}

Based on a report from the World Tourism Organization (WTO, 1995), the tourism industry employs in excess of 11,194,418 people worldwide and represents approximately 5 per cent of the world's total travel and tourism workforce. Monterrubio and Espinosa (2013) significantly found in their study that the characteristics of tourism employment for instance occupation, skills and gender are varied among destinations. The World Bank Report (2013) highlighted that Malaysia's rapid economic growth accompanied with labour market shortages for unskilled workers continue to attract foreign workers from neighbouring countries. Harrison (1992) found that in Kenya, where despite the high 
numbers of new jobs created by tourism, regional unemployment remained high because of the large numbers of migrants who sought work within the tourism sector. Further, according to Lee-Ross and Pryce (2010), the presence in large numbers of migrant workers in hospitality organizations is of consequence for tourism academics as it carries implications for both destination image and the tourist experience of the destination.

Migrant workers are believed to play an essential role in many sectors of the Malaysian economy, including manufacturing, for the foreseeable future (Robertson, 2008). Generally, Ali (2003) divided migrant workers in Malaysia into three categories. The first category consists of the non-citizens of Malaysia who have been staying in the country for a long time and are not allowed to work unless they have work permits produced by the Labour Ministry. This is followed by the second category consisted of migrant workers who are highly skilled and are professionals in the technical and administration field. Finally, the third group is migrant workers who are semi or unskill that enter the country illegally. Meanwhile, migrants have also been classified into various groups such as; temporary migrants, irregular migrants, refugees, forced migration, highly skilled and business migrants and family members (Castles, 2000).

In terms of wages and treatment in workplace, foreign workers should receive the equal treatment as local. According to Shuto (2006), besides being part of a social process, the foreign workers are further expected to be associated with issues like economic market, transnational offering of labour and the change of policies in importing. As for Malaysia, several factors determined the reason for migration such as major development, increment in the economy, lack of work force in the importing countries and change in process of goods (Ajis et al., 2014). In a previous study, Williams (2012) noted that several factors contributed to the employment of migrant workers in the tourism industry for instance low wages, the detachment of skills from productivity, weak internal labour markets, and the importance of non-material rewards. Similarly, other studies highlighted that migrant workers are seen as mobile international workforce which offers a solution to labour shortages where the local workforce is not willing to engage in low pay, low status and seasonal employment (Choi et al., 2000; Williams \& Hall, 2000).

Etzo et al., (2014) in their study described the impact of migration on tourism as two-fold impact which is pulled by immigrants living in a country and the other one is pushed by the country citizens residing abroad. Previously, a study by Mohamed et al. (2012) on the impact of employment of foreign workers in Malaysia indicated that having foreign workers coming into Malaysia is vital particularly to the country's economy. Their study concluded that hiring foreign workers will bring benefits to the country and at the same time will also harm and threaten the country. In a recent study, Mohamed et al. (2016) believed that migration would become a foe of the tourism's image credibility. On the other hands, they also found that migrant workers would be helful to the society even though there would be some who are irresponsible and contribute to the increasing number of crime.

There have been few studies on migrant workers in tourism and hospitality industry. Chartouni (2011) conducted a study in the UAE and found that the UAE labour market consists largely of expatriates rather than nationals, the vast majority of whom are employed in the private sector. It was concluded in the study that the UAE is almost exclusively confined to migrant workers. In a study by Nachmias (2015), it was indicated that the development of migrant employees may help enhance the hotel performance in the long-term. Hence, most hotels in Cyprus only provide operational, informal level training to all their migrant workers. The study also suggested that the Cypriot hotels need to focus their attention on their long-term strategic goals. 


\section{METHODOLOGY}

The target population of the study was the international migrant workers who are legally working in the tourism and hospitality industry in Langkawi. Since there is no exact number of the international migrant workers in the service sector specifically in Langkawi, the number of population was determined according to the general number of international migrant workers in the service sector in Malaysia as stated by the Department of Statistic Malaysia (2012). There was 291,997.44 number of international migrant workers in the service sector and using a table of sample size provided by Krejcie and Morgan (1970), 384 number of respondents was selected to represent the sample. To obtain a balance number of questionnaires distributed to the sectors, 400 respondents and 20 sectors were selected for the study. Hence, each sector was provided with 20 questionnaires to be filled up by the respondents. The sectors were selected at Pantai Cenang area due to the fact that it consisted of most tourism and hospitality sectors.

\section{FINDINGS}

\section{International migrant workers profiles}

As for their skills level, the findings indicated that majority of the respondents are semi-skilled labours (66.3\%) while the rest is unskilled labours (33.7\%).

Table 1. The profiles of international migrant workers

\begin{tabular}{|c|c|c|c|}
\hline Items & Frequency & Percent & Cumulative Percent \\
\hline $\begin{array}{c}\text { Gender: } \\
\text { Male } \\
\text { Female }\end{array}$ & $\begin{array}{c}182 \\
76\end{array}$ & $\begin{array}{l}70.5 \\
29.5\end{array}$ & $\begin{array}{c}70.5 \\
100.0\end{array}$ \\
\hline $\begin{array}{c}\text { Age: } \\
\text { Below } 18 \text { years old } \\
18-30 \text { years old } \\
31-50 \text { years old } \\
\text { Above } 50 \text { years old } \\
\end{array}$ & $\begin{array}{c}7 \\
179 \\
70 \\
2 \\
\end{array}$ & $\begin{array}{l}2.7 \\
69.4 \\
27.1 \\
0.8\end{array}$ & $\begin{array}{c}2.7 \\
72.1 \\
99.2 \\
100.0 \\
\end{array}$ \\
\hline $\begin{array}{c}\text { Marital status: } \\
\text { Single } \\
\text { Married } \\
\text { Divorced } \\
\text { Others }\end{array}$ & $\begin{array}{c}134 \\
104 \\
11 \\
9\end{array}$ & $\begin{array}{c}51.9 \\
40.3 \\
4.3 \\
3.5\end{array}$ & $\begin{array}{c}51.9 \\
92.2 \\
96.5 \\
100.0\end{array}$ \\
\hline $\begin{array}{l}\text { Skills level: } \\
\text { Unskilled } \\
\text { Semi-skilled }\end{array}$ & $\begin{array}{c}87 \\
171 \\
\end{array}$ & $\begin{array}{l}33.7 \\
66.3 \\
\end{array}$ & $\begin{array}{c}33.7 \\
100.0\end{array}$ \\
\hline $\begin{array}{c}\text { Proficiency in English: } \\
\text { Very little } \\
\text { Little } \\
\text { Good } \\
\text { Very good }\end{array}$ & $\begin{array}{l}44 \\
63 \\
93 \\
58\end{array}$ & $\begin{array}{l}17.1 \\
24.4 \\
36.0 \\
22.5\end{array}$ & $\begin{array}{c}17.1 \\
41.5 \\
77.5 \\
100.0\end{array}$ \\
\hline $\begin{array}{c}\text { Number of years working in the sector: } \\
\text { Less than } 1 \text { year } \\
1-5 \text { years } \\
6-10 \text { years } \\
\text { More than 10 years }\end{array}$ & $\begin{array}{c}63 \\
159 \\
31 \\
5\end{array}$ & $\begin{array}{c}24.4 \\
61.6 \\
12.0 \\
1.9\end{array}$ & $\begin{array}{c}24.4 \\
86.0 \\
98.1 \\
100.0\end{array}$ \\
\hline $\begin{array}{l}\text { Income per month: } \\
\text { Less than RM1,000 } \\
\text { RM1,000 - RM4,999 } \\
\text { RM5,000 - RM9,999 } \\
\text { More than RM10,000 }\end{array}$ & $\begin{array}{c}40 \\
215 \\
2 \\
1\end{array}$ & $\begin{array}{c}15.5 \\
83.3 \\
0.8 \\
0.4\end{array}$ & $\begin{array}{r}15.5 \\
98.8 \\
99.6 \\
100.0\end{array}$ \\
\hline
\end{tabular}


Additionally, majority of them also stated that they can speak good English (36.0\%) and very good English (22.5\%). The remaining stated as can speak little English (24.4\%) and very little English (17.1\%). As for the question on the number of years working in the sector, the findings highlighted that majority of the respondents have been working between $1-5$ years $(61.6 \%)$. This is followed by $24.4 \%$ of them have been working less than 1 year, $12.0 \%$ have been working between $6-10$ years and the remaining $1.9 \%$ have been working for more than 10 years. Interestingly, most respondents received an income between RM1,000 - RM4,999 per month (83.3\%), and only few received an income less than RM1,000 (15.5\%) while the remaining received between $\mathrm{RM}_{5}, 000$ and more than RM10,000 income per month. The respondents were further asked to state their country of origin (Figure 2). The findings of the survey indicated the highest percentage are from Indonesia (21.3\%). The findings then revealed that $17.8 \%$ respondents are from India, followed by $15.9 \%$ respondents from Bangladesh, 12.4\% from Philippines, 8.5\% from Thailand, 2.7\% from Pakistan and $0.4 \%$ from Vietnam. However, the findings also indicated that $20.9 \%$ respondents are from other countries such as Nepal, United Kingdom and few are from Maldives.

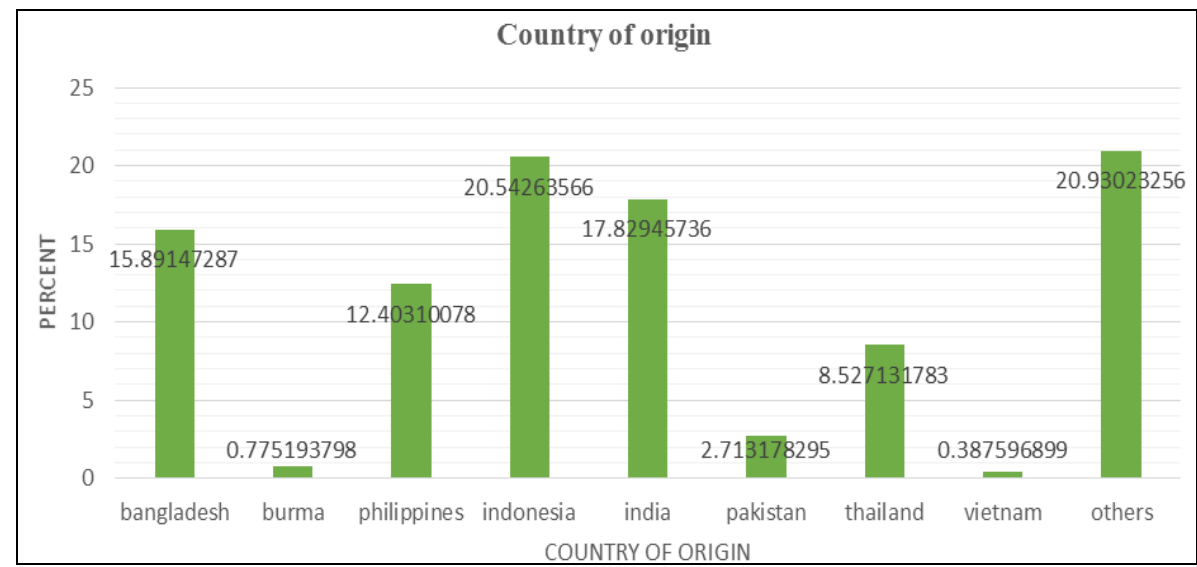

Figure 2. Country of origin

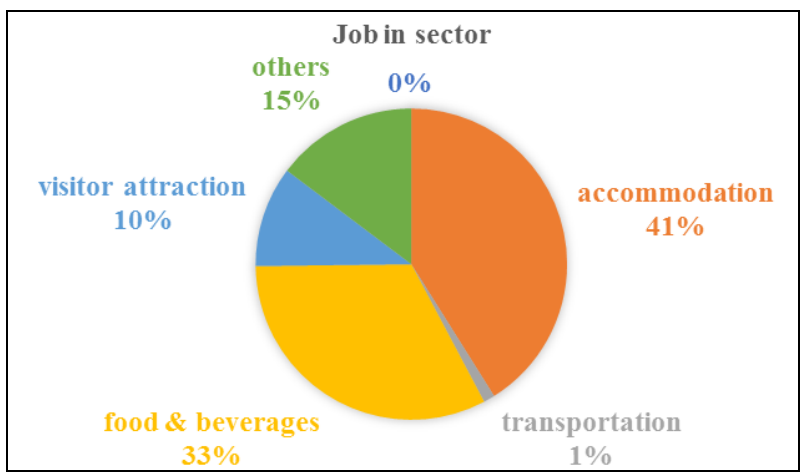

Figure 3. Job in the sector

Further, the respondents were asked to provide their working sector (Figure 3). It was noted that most of them are working in the accommodation sector (41.1\%), followed by the food and beverages sector (32.6\%), other tourism and hospitality related sectors (14.7\%), the visitor attractions sector (10.5\%) and the transportation sector $(1.2 \%)$. The 
survey question further asked the respondents to indicate their position in the sector (Figure 4). Majority of them involved in the customer service (75.6\%), followed by other positions (12.4\%), administration (6.2\%) and only few in the security service $(5.8 \%)$.

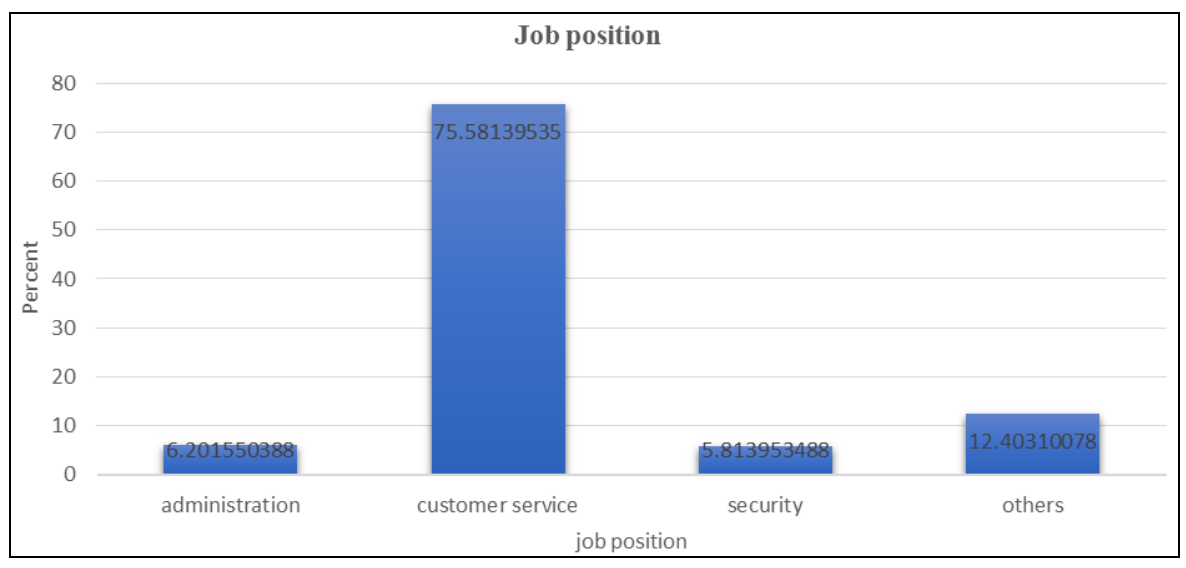

Figure 4. Job position

Factors motivate the international migrant workers to work in the industry

The respondents were then asked to indicate their agreement on the factors motivating them to work in the tourism and hospitality industry. Eight factors were identified and listed in the questionnaire survey namely, love meeting with people, easy to get jobs in the industry, to gain new experience, following their friends, following their families, high wages offered by the industry and also other motivational factors. The findings of the study indicated that majority of the respondents found that the major factor motivated them to work in the industry is to gain new experience $(52.3 \%)$. The second factor which they noted is love meeting with people (28.3\%), followed by the third factor, easy to get jobs (22.1\%) and finally few of them stated that following friends as the one of the major factors motivating them. The findings however noted that other factors listed were not considered as major factors motivating the international migrant labours to work in the tourism and hospitality industry in Langkawi including the high wages (5.4\%).

Table 2. Factors motivating

\begin{tabular}{lcc}
\hline \multicolumn{1}{c}{ Items } & Yes (\%) & No (\%) \\
\hline To gain new experience & 52.3 & 47.7 \\
Love meeting with people & 28.3 & 71.7 \\
Easy to get jobs & 22.1 & 77.9 \\
Following friends & 12.0 & 88.0 \\
Easy to be promoted & 7.8 & 99.2 \\
Following families & 7.4 & 92.6 \\
Other factors & 7.4 & 92.6 \\
High wages & 5.4 & 94.6 \\
\hline
\end{tabular}

\section{DISCUSSION AND CONCLUSION}

Based on the findings, it can be concluded that the profiles of international migrant workers in the Langkawi tourism and hospitaity industry is quite significance to the growth of the industry. It is noted in the study that majority of the international migrant workers in Langkawi was male within the ranged of age between $18-30$ years 
old. Additionally the international migrant workers dominant the category of single and married. The findings also noted that majority of the international migrant workers came from Indonesia, India and Bangladesh. Whilst only few of them came from other neighboring country such as Thailand and Vietnam. They eventually had good qualification and can performed their tasks in the customer service sector.

More, the accommodation sector is noted by the international migrant workers as the major sector they had chosen to work within the industry. The reasons are basically because they find it was easy to get job in the sector and further, they also believed that the accommodation sector offered attractive incentives for instance free meal, free accommodation and free medical/insurance compared to other sectors. Additionally, it is noted that there were several factors motivating the international migrant workers to work in the industry. Majority of them were working in the industry in order to gain new experience, besides they loved meeting with people. They had also choosen the industry to work because they wanted to follow their friends. Generally, the findings highlight the importance of having international migrant workers in the tourism and hospitality industry which is in line with other studies such as Robertson (2008), Chartouni (2011), Mohamed et al., (2012; 2016) and Nachmias (2015). Moreover, it is also consistent to what was suggested by Baum (2012) where the migrants are considered as a vital source of skills and labour for the hotel industry. Hence, the hotel industry would in turn, provides an important source for internal and international migrants seeking temporary or permanent employment opportunities away from their home communities.

The study however had involved the international migrant workers who were legally working in the tourism and hospitality sectors in Langkawi. More, the study had only focused on Langkawi since it is a world known tourist destination which composed of various hospitality sectors and eventually consisted of many international migrant workers. The respondents were also consisted of skilled and semi-skilled workers excluding the expatriates. Subsequently, the findings may only present those international migrant workers who majority were working at the lower managerial level. It is suggested that for future research, the international migrant workers would include all categories of workers in the tourism and hospitality sectors in Langkawi.

\section{Acknowledgements}

The study was sponsored by the Malaysian Ministry of Higher Education under the Fundamental Research Grant Scheme (FRGS) S/O code 13029.

\section{REFERENCES}

Ajis, M.N., Keling, M.F., Othman, Z., \& Shuib, M.S. (2014). The dilemma of managing foreign workers in Malaysia: opportunities and challenges. Global Journal of Human Social-Science:Political Science, 14(4):43-53.

Ali, Jamal. (2003). Ekonomi Malaysia: Satu Analisis Dasar (Malaysia Economics: Policy Analysis). Kuala Lumpur: Dewan Bahasa dan Pustaka.

Anand, S., \& Sen, A. (2000). Human development and economic sustainability. World Development, 28(12):2029-2049.

Baum, T. (2012). Migrant workers in the international hotel industry. International Migrant paper No. 112, Geneva: ILO.

Castles, S. (2000). International migration at the beginning of the twenty-first century: global trends and issues. Global Trends and Issues, UNESCO, 165/2000:269-281.

Chatouni, C. (2011). Essays on the Labor Market of the United Arab Emirates, Unpublished PhD dissertation, Graduate School of Arts and Sciences, Georgetown University: Washington, DC.

Choi, J. G., Woods, R. H., \& Murrmann, S. K. (2000). International labor markets and the migration of labor forces as an alternative solution for labor shortages in the hospitality industry. International Journal of Contemporary Hospitality Management, 12(1):61-67.

Cukier-Snow, J., Wall, G. (1993). Tourism employment: Perspectives from Bali. Tourism Management, 14:195-201.

Etzo, I., Massidda C., \& Piras, R. (2014). Migration and outbound tourism: evidence from Italy. Annals of Tourism Research, 48:235-249. 
Halim, S.A., Komoo, I., Salleh, H., \& Omar, M. (2011). The geopark as a potential tool for alleviating community marginality. The International Journal of Research into Island Cultures, 5(1):94-113.

Halseth, G. (1999). We came for the work: situating employment migration in B.C.'s small, resource-based, communities. The Canadian Geographer, 43(4):363-81.

Harrison, D. (1992). International tourism and the less developed countries. The background. In Harrison, D. (ed.) Tourism and the Less Developed Countries. London: Belhaven Press.

Hjalager, A., \& Andersen, S. (2001). Tourism employment: Contingent work or professional career? Employee Relations, 23(2):115-129.

Janta, H., Brown, L., Lugosi, P. \& Ladkin, L. (2011). Migrant relationships and tourism employment. Annals of Tourism Research, 38(4):1322-1343.

Joppe, M. (2012). Migrant workers: Challenges and opportunities in addressing tourism labour shortages. Tourism Management, 33(3):662-671.

Keep, Ewart, \& Ken Mayhew. (1999). Skills task force research group. Paper 6. The leisure sector. London: DFEE.

Krakover, S. (2000). Partitioning seasonal employment in the hospitality industry. Tourism Management, 21:461-471.

Krejcie, R.V., Morgan, D.W. (1970). Determining sample size for research activities. Educational and Psychological Measurement, 30:607-610.

Lee-Ross, D., \& Pryce, J. (2010). Human resources and tourism. Skills, culture and industry. Bristol: Channel View Publications.

Mohamed, B., Mohd Paisar, S., \& Mohd Nain, F.H. (2016). The impacts of foreign workers to Malaysian tourism. Proceedings of 20th IASTEM International Conference, Sydney, Australia, 15th April 2016, ISBN: 978-93-85973-87-1.

Mohamed, M.H., Ramendran, C., \& Yacob, P. (2012). The impact of employment of foreign workers: Local employability and trade union roles in Malaysia. International Journal of Academic Research in Business and Social Sciences, 2(10):530-541.

Monterrubio, J.C., \& Espinosa, B. (2013). Characterisation of ecotourism employment in a developing world destination. GeoJournal Tourism and Geocities, 1(11):54-65.

Nachmias, S., Johnston, A, \& Meade, C. (2015). Migrant workers and human resource development practices in the hotel sector: a case of Cyprus. 6th International Conference on Human Resource Development Research and Practice across Europe, University College Cork, Cork, Republic of Ireland, 3-5 June 2015.

Pantelidis, I., \& Wrobel, S. (2008). London's hospitality workforce, cultural diversity a choice or necessity? London Journal of Tourism, Sport and Creative Industries, 1(1):13-21.

Robertson Jr, P.S. (2008). Migrant workers in Malaysia-issues, concerns and points for action. Fair Labor Association: 1-15.

Saunders, K. C. (1981). Social Stigma of Occupations. Farnborough: Gower.

Shuto, Motoko. (2006). Labour Migration and Human Security. In Harald Kleinschmidt (Ed). Migration, Regional Integration and Human Security: The Formation and Maintenance of Transnational Spaces. Hampshire: Ashgate Publishing Limited: 205-224

Wickramasekara, P. (2002). Asian labour migration: issues and challenges in an era of globalization. International Migration Papers No. 57, Geneva: ILO.

Williams, M. (2012). Tourism, migration and human capital: knowledge and skills at the intersection of flows, in W C Gartner and C Hsu (eds.), The Routledge Handbook of Tourism Research, London: Routledge: 251-264.

Williams, A., \& Hall, C.M. (2000). Tourism and migration: new relationships between production and consumption. Tourism Geographies, 2(1):5-27.

*** CTHRC. (2003). About the CTHRC, Canadian Tourism Human Resource Council. 2003.

*** Department of Labor Peninsular (2014). A report prepared for the Ministry of Human Resources Malaysia. Retrieved from www.mida.gov.my

*** Department of Statistics Malaysia. (2012). Retrieved from. https://www.statistics.gov.my

*** International Labour Office. (1989). Hotel, catering and tourism committee: Productivity and training in the hotel, catering and tourism sector. Geneva: International Labour Office.

*** LADA (Langkawi Development Authority). (2016). Tourist Arrival in Langkawi [Online]. http://www.lada. gov.my/Langkawi/statistic.htm.

*** Map of Langkawi. (2012). Retrieved from https://thirdculturekidparis.wordpress.com

*** Ministry of Home Affair. (2015). International migrant workers in Malaysia. Retrieved from www. data.gov.my.

*** Tourism Malaysia. (2016). Tourism Malaysia: Media Centre. Available [Online]. http://www.tourism.gov. my/corp/media/default.asp.

*** Workforce Department. (2004). The Malaysian economy in 2004. Retrieved from. www.bnm.gov.my

*** World Bank Report. (2013). Immigration in Malaysia: Assessment of its economic effects and a review of the policy and system. Report completed in collaboration with Ministry of Human Resource of Malaysia.

*** World Tourism Organization - WTO. (1995). Retrieved from. www.statistics.unwto.org

Submitted:

15.11.2018
Revised:

o8.03.2019
Accepted and published online 12.03.2019 